\title{
The Dilemma of Client Clearing in the OTC Derivatives Markets
}

\author{
Jo Braithwaite ${ }^{1}$
}

Published online: 6 October 2016

(C) The Author(s) 2016. This article is published with open access at Springerlink.com

\begin{abstract}
The global crisis triggered a vast programme of financial markets reform, including a new regime for over-the-counter (OTC) derivatives which requires hitherto private contracts to be cleared through central counterparties (CCPs). This article argues that the interaction between underlying law and this new regulation needs to be addressed in order to advance the objectives of the reforms. The starting point for the argument is the two techniques that underpin CCPs: limited access and posting assets, or margin. Having established that access via intermediated or 'client' clearing will become increasingly important with mandatory clearing, the article explores the impact of client clearing on the legal rules governing the margin posted by users of a CCP. The detail of the interaction between European regulations on CCP clearing and the UK rules on client assets is considered as an example. The dilemma identified arises because regulation, designed to improve financial stability by mandating clearing, may potentially undermine certain ways in which CCPs promote that outcome. The article concludes that the interaction between underlying law and new regulation needs to be accounted for and addressed at EU level, in order to safeguard the functions that attracted regulators to clearing in the first place.
\end{abstract}

Keywords Clearing $\cdot$ CCPs $\cdot$ Derivatives $\cdot$ EMIR $\cdot$ Margin $\cdot$ CASS

Jo Braithwaite

j.p.braithwaite@1se.ac.uk

1 Department of Law, London School of Economics and Political Science, London, UK 


\section{Introduction}

Central counterparties (CCPs) are post-trade, pre-settlement market infrastructure. They clear contracts of many kinds by becoming buyer to every seller and seller to every buyer. A combination of legal techniques including novation, netting and asset-backing enables CCPs to assume market participants' counterparty credit risk and act as a 'shock absorber' by mutualising losses in times of market failure. For this reason, CCPs can be thought of as 'legal devices', where the underlying legal techniques both explain and constrain how clearing services work. ${ }^{1}$

This legal perspective helps to evaluate the robustness of market infrastructure like CCPs. For instance, it offers a way of exploring the interaction between different legal techniques, and how those techniques may be complicated by exogenous factors like new financial markets regulation. Building on this insight, this article offers an analysis of the interaction between two of a CCP's key risk management tools, being selective membership and collecting margin, and the new regulatory regime for over-the-counter (OTC) derivatives. ${ }^{2}$ The central thesis developed here is that reforms designed to address one lesson of the financial crisis (the risk that built up in the OTC derivatives markets) must now address another such lesson (namely, the risk associated with client assets).

The analysis is developed in three Sections. Section 2 discusses the regulatory context and explains the newly enhanced role for CCPs in the "perimeter-changing measures ${ }^{3}$ implemented worldwide since the financial crisis. Section 3 turns to the question of the interaction between new regulation and access to CCPs. It starts by cautioning that the introduction of compulsory clearing potentially conflicts with CCPs' autonomy because such a rule is premised on all non-exempt market participants being able to gain access to clearing services. As the article demonstrates, this conflict is mitigated, but not solved, by the possibility of alternative routes to clearing services, through a CCP member. As the article explains, this means that one of the effects of the new regulatory regime for OTC derivatives will be to increase the importance of the legal structures behind 'client clearing' arrangements. With this in mind, Sect. 4 of the article explores how client clearing complicates the provision of margin to CCPs. In particular, this part of the article argues that CCP members which clear for clients are subject to a patchwork of rules, as the clearing and client assets regimes sit awkwardly together. The interaction between the European clearing regime and the UK rules on client money, recently overhauled as a direct result of the financial crisis, are considered by way of example. The article concludes that the interaction between new regulations mandating clearing and the underlying law needs to be addressed at EU

\footnotetext{
Braithwaite (2011).

2 Derivatives are bilateral contracts under which the rights and obligations derive from an underlying asset, index or benchmark, e.g., interest rate swaps. See the definition of derivatives and accompanying discussion in Benjamin (2007), at p. 65. For a discussion of OTC derivatives, see text accompanying notes 14 and 15 below.
}

3 Moloney (2014), at p. 34. 
level in order to safeguard the functions that attracted regulators to clearing in the first place.

\section{The Regulatory Context}

In the immediate aftermath of the global financial crisis, the G20 quickly turned its attention to reforming the OTC derivatives markets. This ambitious use of political capital reflected the fact that various types of these privately traded derivatives, especially credit default swaps (CDS), were implicated in disasters like the nearcollapse of AIG. ${ }^{4}$ Accordingly, the statement issued after the G20's September 2009 Pittsburgh meeting included the declaration that all 'standardized OTC derivatives contracts' should be 'traded on exchanges or electronic trading platforms, where appropriate' and cleared through CCPs by 'end-2012'.5 These measures have subsequently become 'one of the defining features of the G20's reform programme ${ }^{6}$ seeking to increase financial stability by addressing the concentration of risk, to increase market resilience, and to improve the transparency of these opaque markets. ${ }^{7}$

One of the central planks of the G20 reform agenda is that standardised OTC derivatives must be cleared through a CCP, rather than remaining as private, bilateral contracts between counterparties, where each assumed the credit risk of the other's default. Why would the G20 seek to impose this particular reform? One reason identified in the literature is that CCPs performed effectively during the crisis, even being described as the 'unlikely heroes' of the collapse of the Lehman Brothers group. ${ }^{8}$ This high-profile demonstration of the benefits of CCPs in contributing to market resilience seems to have helped influence the G20's decision to make the clearing of eligible contracts mandatory. ${ }^{9}$

The G20's agenda has triggered complex legislative activity worldwide, but, despite the stated deadline of 'end-2012', it has not been fully implemented in any jurisdiction yet. ${ }^{10}$ In the EU, this new regulatory regime is to be found in the

\footnotetext{
${ }^{4}$ National Commission on the Causes of the Financial and Economic Crisis in the United States (2011), Chapter 19.

5 G20 Leaders' Statement (2009), at p. 9.

6 Moloney (2014), at p. 573.

7 Reflected in the Recitals of EMIR, e.g., Recital 4, which states that the Regulation seeks to mitigate risks relating to interdependence in the OTC derivatives markets and to improve the transparency of derivative contracts. Regulation (EU) No 648/2012 of 4 July 2012 on OTC derivatives, central counterparties and trade repositories. This Regulation is known as the European Market Infrastructure Regulation, hereafter 'EMIR'.

8 Norman (2011), at p. 3 and Chapter 3 generally.

9 See, e.g., Lane et al. (2013), at p. 170: 'This [G20] commitment arose directly from the experience of the global crisis: markets for OTC derivatives that were settled bilaterally lacked transparency with respect to exposures and concerns about counterparty default intensified during the crisis, transmitting stress throughout the global financial system.' See also Norman (2011), at p. 47: 'The success of the LCH.Clearnet Group and other clearing houses in the aftermath of the Lehman bankruptcy made clearing OTC trades a high priority for policy makers in their efforts to learn from the financial crisis.'

${ }^{10}$ This piecemeal progress is helpfully charted by the Financial Stability Board in its regular Implementation Reports. Financial Stability Board (2014), Appendices A-E inclusive.
} 
European Market Infrastructure Regulation (EMIR) ${ }^{11}$ and the 2014 MiFID II/MiFIR regime. ${ }^{12}$ The 'clearing obligation' itself is found in Article 4 of EMIR, which is fleshed out in Commission Delegated Regulation 149/2013. ${ }^{13}$ The obligation applies to 'OTC derivatives contracts', where the definition of derivative is that used in MiFID I, ${ }^{14}$ and 'OTC' is defined as contracts which have not been executed on a 'regulated market'. ${ }^{15}$

Under Article 4, OTC derivatives contracts will be subject to mandatory clearing if two conditions are met. First, that type of derivative must have been declared subject to the clearing obligation and entered in a public register maintained by the European Securities and Markets Authority (ESMA). ${ }^{16}$ EMIR provides that classes of contracts may become subject to the clearing obligation either by a 'top down' approach initiated by ESMA acting 'on its own initiative', or by a 'bottom up' approach, based on classes of contracts already cleared by CCPs. ${ }^{17}$ Pursuant to the latter, on 6 August 2015, the European Commission adopted a Delegated Regulation to implement the clearing obligation as regards certain interest rate swaps. ${ }^{18}$ This obligation will start to apply at different times, depending on the category of counterparty to the contract. These start times range from 6 months to 3 years from the entry into force of the Delegated Regulation. This is the first clearing obligation to be implemented under EMIR.

The second condition for the clearing obligation to apply is that the contracts involved must be between certain types of parties, as set out in Article 4 of EMIR. The starting point is that the obligation will apply to contracts concluded 'between two financial counterparties' (FCs). ${ }^{19}$ FCs are defined in Article 2(8) of EMIR. The definition is broad and includes investment firms, credit institutions, UCITS, insurance and reinsurance undertakings, and alternative investment funds. Under

\footnotetext{
${ }^{11}$ EMIR, supra n. 7.

${ }^{12}$ Markets in Financial Instruments Directive 2014/65/EU (MiFID II) and Markets in Financial Instruments Regulation (EU) No 600/2014 (MiFIR), collectively the 'MiFID II/MiFIR regime'. EMIR does not cover derivatives traded on a 'regulated market' though MiFIR includes a separate obligation that these products must be cleared. The MiFID II/MiFIR regime also implements the G20's reform agenda for the OTC markets, and it 'is designed to be closely aligned with EMIR' (Moloney 2014, at p. 623). While the MiFID II/MiFIR regime raises important issues for CCPs, including as a consequence of the requirement that clearable derivatives agreed on trading venues are cleared promptly, and about how trading venues access CCPs, this article focuses on the clearing obligation under EMIR and membership of CCPs themselves.

${ }^{13}$ Commission Delegated Regulation (EU) No 149/2013 of 19 December 2012. For discussion of the role of the European Securities and Markets Authority (ESMA), which publishes and consults on these regulatory technical standards and proposes them to the Commission, see Moloney (2014), at p. 577 (in the context of EMIR) and at pp. 920-938 (ESMA's role more generally).

${ }^{14}$ Markets in Financial Instruments Directive 2004/39/EC (MiFID I). The definition is as set out in points (4) to (10) of Section C of Annex 1 and cross-referenced in Article 2(5) of EMIR.

${ }_{15}$ Article 2(7) of EMIR, cross-referencing the definition in Article 4(1)(14) of MiFID I.

${ }^{16}$ Article 6(1) of EMIR.

${ }^{17}$ Articles 5(3) and 5(2) of EMIR, respectively.

18 Commission Delegated Regulation (EU) 2015/2205 supplementing Regulation (EU) No 648/2012 of the European Parliament and of the Council with regard to regulatory technical standards on the clearing obligation.

19 Article 4(1) of EMIR.
} 
Article 4, the clearing obligation will also apply to a contract where one or both parties is a 'non-financial counterparty' (NFC), as long as the NFC exceeds the clearing threshold. ${ }^{20}$ NFCs are defined as undertakings established in the European Union other than CCPs and FCs. ${ }^{21}$ As noted later in this article, this definition of FC and NFC catches a far greater range of parties than are currently members of UK CCPs.

Contracts involving NFCs will not have to be cleared unless the NFCs involved exceed the 'clearing threshold'. 22 These thresholds have been set by the Commission, with the figures provided for each of five asset classes, including $€ 1$ billion gross notional value for credit derivatives and $€ 3$ billion gross notional value for interest rate derivatives. ${ }^{23}$ An NFC over the individual threshold in any category (called an NFC +$)^{24}$ will have to clear all classes of derivatives (whether entered into for hedging or speculating) for as long as it is over any of the thresholds.

While the EMIR clearing obligation broadly tracks that found in Title VII of the Dodd-Frank Act, ${ }^{25}$ there are significant differences between the two regimes. This is a source not only of political controversy, ${ }^{26}$ but also of friction for entities having to comply with both sets of rules. ${ }^{27}$ In the US, the mandatory clearing of standardised interest rate swaps and credit derivatives has been phased in since 2013, with the timing depending on the type of party involved in the trade.

Looking at the worldwide OTC markets, though the clearing obligation has not yet come into force in many jurisdictions, there is already significant, and growing, use of clearing. The Bank of England reports that $50 \%$ of the global OTC interest rate derivatives market was centrally cleared in January 2015, compared to $31 \%$ in April 2012. ${ }^{28}$ Notwithstanding the delayed and piecemeal implementation of the

\footnotetext{
20 Article 4(1)(a) of EMIR.

21 Article 2(9) of EMIR.

22 Article 10(1)(b) of EMIR.

23 Article 11, Commission Delegated Regulation (EU) No 149/2013, setting out the clearing threshold values for the purpose of the clearing obligation. See also the accompanying information for UK NFCs provided by the UK Financial Conduct Authority (FCA), Obligations for non-financial counterparties under EMIR: the hedging definition and the clearing threshold, at http://www.fca.org.uk/firms/markets/ international-markets/emir/obligations-non-financial-counterparties. Accessed 4 November 2015.

24 See guidance on the obligations of NFC + entities at FCA, ibid.

25 Dodd-Frank Wall Street Reform and Consumer Protection Act 2010, H.R. 4173.

26 See, e.g., Rennison (2015), discussing disagreement between EU and US regulators on levels of margin to be posted to CCPs in relation to futures trades and describing a '2-year spat over recognition of each other's rules'.

27 Many financial services firms now offer comparative guides to Dodd-Frank and EMIR which illustrate the onerous task for clients having to comply with both. See, e.g., PWC (2013), which explains: 'The bottom line: get ready for an expensive undertaking as you conform to at least two sets of global derivatives rules.'

28 Bank of England (2015), para 1.1, citing data from DTCC trade information warehouse reports and Bank calculations.
} 
G20's agenda, therefore, CCP clearing has already become a vitally important part of the global financial market infrastructure. ${ }^{29}$

\section{The Clearing Obligation and Access to CCPs}

\subsection{Users of Derivatives}

The clearing obligation in EMIR potentially applies to a broad range of market participants, including, as shown, not only FCs but also NFC+s. This is not just a moot point: OTC derivatives have always had a very broad range of uses and users. ${ }^{30}$ A recent research study published by ISDA $^{31}$ demonstrates how trades involving diverse participants have become a more significant portion of market turnover in the last decade. Based on data published by the Bank for International Settlements (BIS), ISDA reports that in 2013, $65 \%$ of the OTC derivatives markets by turnover were trades between reporting dealers (i.e., major banks and securities houses) ${ }^{32}$ on the one hand, and 'other financial institutions' such as pension funds, or non-financial counterparties such as manufacturers, on the other. Accordingly, only $35 \%$ of the market by turnover were trades where both parties were reporting dealers (and, as ISDA points out, some of this is necessary to support client trading). ${ }^{33}$

As a result, we need to consider the types of entities which may need (or wish) to access clearing services for OTC derivatives under the new global regulatory regime, alongside the types of entities that are able or willing to become members of CCPs and thereby able to access clearing direct. Having established a potential mismatch between members and parties requiring access, the next part of the article explains how this problem is mitigated, though not solved, by structures allowing alternative ways of accessing clearing.

\subsection{Membership}

Article 2(14) of EMIR defines a 'clearing member' as 'an undertaking which participates in a CCP and which is responsible for discharging the financial obligations arising from that participation'. This definition neatly captures the

\footnotetext{
29 This development, along with parallel reforms to other financial market infrastructure, is explained in terms of an expansion of 'public' markets and corresponding 'shrinkage' of 'private' markets by Ferrarini and Saguato (2015). Morgan (2012) explains the complexity of implementing the clearing mandate, which he calls a 'technical fix', by considering the regulatory and political context. For an overview of recent developments in the $\mathrm{CCP}$ sector, and an evaluation of the risks of mandatory clearing generally, see Persaud (2015).

30 See, e.g., Benjamin (2007), at pp. 86-91, and Braithwaite (2012).

31 ISDA (2014). The International Swaps and Derivatives Association (ISDA) is the trade association for participants in the OTC derivatives markets, with over 850 members in 68 countries. See http://www2. isda.org/about-isda/. Accessed 4 November 2015.

32 '[A]pproximately 400 large commercial and investment banks and securities houses in 47 countries, including their branches and subsidiaries worldwide' take part in the BIS derivatives survey. ISDA (2014), at p. 17.

33 Ibid, at p. 6.
} 
linked rights and responsibilities involved in CCP membership. Members may access clearing services and enjoy the security of facing a CCP rather than facing a market counterparty, whose counterparty risk they might have had to manage with collateral or guarantees or other third-party promises. In return, members must post margin to their CCP and contribute to a shared, pre-funded default fund. They also assume operational and administrative obligations towards running the $\mathrm{CCP}$, as set out in a detailed membership agreement. For example, upon a fellow member's default, non-defaulting members may be expected to participate in an auction of the defaulter's positions. ${ }^{34}$ This symbiosis helps to explain why a CCP must be so careful about selecting and monitoring its members.

The membership criteria for clearing services for OTC derivatives are onerous, even by the standards of other clearing services. This is because a CCP faces more risk clearing OTC derivatives, which have high values and long maturities compared to other cleared contracts (e.g., for commodities), while the operational complexities involved in clearing OTC derivatives are also far greater. ${ }^{35}$ LCH.Clearnet's published rules, for example, require that parties applying to be an individual clearing member of EquityClear have a minimum net capital of $£ 5$ million. ${ }^{36}$ By way of comparison, an applicant to be a type of member called a futures commission merchant (FCM) Clearing Member of its SwapClear service for interest rates swaps must maintain an adjusted minimum net capital of $\$ 50$ million. $^{37}$

Article 37 of EMIR, which deals with a CCP's 'participation requirements' sets out, in very broad terms, the objectives which should guide CCPs when setting their membership criteria. CCPs 'shall ensure that clearing members have sufficient financial resources and operational capacity to meet the obligations arising from participation in a CCP' ${ }^{38}$ Further, members must comply with entry criteria on an 'ongoing basis' for the duration of their membership. ${ }^{39}$ A CCP may also impose 'specific additional burdens ${ }^{40}$ on members. In practice, the resulting membership criteria are demanding financially and operationally, both at the time of applying and thereafter. Potential members must demonstrate high levels of technical capacity and satisfy numerous corporate governance requirements. ${ }^{41}$ As discussed

\footnotetext{
34 Article 37(6) of EMIR allows CCPs to 'impose specific additional obligations on clearing members, such as the participation in auctions of a defaulting clearing member's position'.

35 EMIR recognises that such concerns underpin membership criteria, stating that they should 'ensure that clearing members have sufficient financial resources and operational capacity to meet the obligations arising from participation in a CCP', Article 37(1) of EMIR.

${ }^{36}$ LCH.Clearnet (December 2013) Clearing house procedures, section 1.8.3, http://www.lchclearnet. com/documents/731485/762789/Section+1.9+of+the+Rulebook/79e561a7-d1d6-497a-8bb3-8b6214d2 880e. Accessed 11 August 2015.

37 This sum is subject to 'scaling' by the clearing house. LCH.Clearnet (April 2014) FCM rulebook, Regulation 102(b)(i), http://www.lchclearnet.com/documents/731485/762789/FCM+Ruleboo/67c306e0ccc2-4022-a864-89cf672e887e. Accessed 11 August 2015.

38 Article 37(1) of EMIR.

39 Article 37(2) of EMIR.

40 Article 37(6) of EMIR.

41 See, e.g., ICE Clear Europe Membership, available at https://www.theice.com/clear-europe/ membership. Accessed 11 August 2015.
} 
by Murphy, members of CCPs may also be required to participate in 'fire drills' where the CCP runs through its procedures for an emergency. ${ }^{42}$ Representatives of members must take part in a CCP's risk committee. ${ }^{43}$ This is not to forget that membership is also expensive, not only because of the requirements to post margin and a default fund contribution, and fees, but also, as Lane, Dion and Slive point out, because of indirect costs through capital requirements. Clearing members which are banks will face increased costs under new regulatory capital rules. Specifically, they will 'incur higher costs on their credit exposures to a $\mathrm{CCP}$, on prefunded default fund contributions and on exposures to clients who clear indirectly through them'. 44

While there is concern amongst international regulators that clearing services and other parts of the financial market infrastructure are accessible, it is notable that the new regulatory framework continues to reserve discretion over membership criteria to CCPs, as long as such measures may be related back to managing risk. Principle 18 of IOSCO's 2012 Principles for Financial Market Infrastructures (PFMIs) ${ }^{45}$ states: 'An FMI should have objective, risk-based and publicly disclosed criteria for participation, which permit fair and open access.' This is implemented in EMIR, which requires membership criteria to be 'non-discriminatory' and to 'ensure fair and open access'. ${ }^{46}$ However, EMIR is also clear in several places that this duty is subject to a CCP's right to control its own risks by selecting members according to its own choice of criteria. For example, Article 37(1) of EMIR states that '[c]riteria that restrict access' are only allowed 'to the extent that their objective is to control risk for the CCP'. ${ }^{47}$ Ultimately, both the PFMIs and EMIR reflect the fact that while openness is important, the safety of the CCP remains the paramount concern.

This all helps to explain the actual number and nature of clearing service members. The Bank of England, which supervises the four UK CCPs, is in the second year of publishing annual reports on financial markets infrastructures. ${ }^{48}$ The latest shows that the four UK CCPs have memberships of 18 (CME Clearing Europe), 43 (LME Clear), 81 (ICE Clear Europe) and 98 (LCH.Clearnet's SwapClear service). ${ }^{49}$ A review conducted by the author of the membership lists

\footnotetext{
42 Murphy (2013), at p. 147.

43 Article 28(1) of EMIR.

44 Lane et al. (2013), at p. 173. The final standard for capital requirements for bank exposures to CCPs was published by the Basel Committee on Banking Supervision in April 2014, to take effect from 1 January 2017. See BCBS (2014).

45 Committee on Payment and Settlement Systems and International Organization of Securities Commissions (2012).

46 Article 37(1) of EMIR.

47 See, e.g., also Article 37(6) of EMIR, and the requirement that the CCP's Risk Committee advise the Board about the impact of membership criteria on 'the risk management of the CCP' (Article 28(3)).

48 Bank of England (2015), and see also Financial Stability Board (2014), Appendix G, which lists central counterparties clearing OTC derivatives worldwide.

49 Bank of England (2015), Annex, at p. 22. Membership numbers are provided here for each UK CCP, apart from for LCH.Clearnet, where data is provided for each of its clearing services. SwapClear has the largest membership of the clearing services listed in this Annex. The second largest is RepoClear at 78 and the smallest Listed Interest Rate at 10.
} 
published on each UK CCP's website ${ }^{50}$ found that there are almost no members of CCPs which are not banks and other types of financial services companies. ${ }^{51}$ This type of membership may make for robust CCPs, but it clearly poses a challenge in a world of mandatory clearing. ${ }^{52}$ In other words, to the extent that (1) membership of CCPs is small and still primarily made up of banks and specialist financial services companies, (2) the definition of FC in EMIR catches a broader range of market participants, such as insurers and asset managers, and (3) NFCs, such as manufacturers or energy companies, fall outside the clearing exemption and are therefore also obliged to clear, it must follow that EMIR will impose the obligation to clear on entities that are not currently members of CCPs.

Thanks to the mutual rights and responsibilities flagged up at the start of this part of the article, addressing this mismatch is not as simple as throwing open membership to any entity required to clear. In fact, mandatory clearing creates a 'membership dilemma', where, on the one hand, regulators require all non-exempt parties to be able to gain access to clearing, while on the other hand, CCPs must continue to be selective about their members in order to function safely, and in the way that made them so attractive to regulators in the first place. This tension between CCP autonomy and inclusiveness is the direct result of regulators having framed compulsory legislation around a private sector legal device designed to mutualise losses for selected participants. As discussed next, this membership dilemma is mitigated, though not solved, by the availability of two further options for accessing clearing.

\subsection{Client Clearing}

EMIR defines a client as 'an undertaking with a contractual relationship with a clearing member of a CCP which enables that undertaking to clear its transactions

\footnotetext{
${ }^{50}$ Membership lists are published by each clearing house on their websites. See ICE Clear Europe at https://www.theice.com/clear-europe/membership, CME Clearing Europe at http://www.cmegroup.com/ europe/clearing-europe/clearing/cme-clearing-europe-members.html, LCH.Clearnet (SwapClear) at http://www.lchclearnet.com/members-clients/members/current-membership, LME Clear at https://www. lme.com/lme-clear/membership/clearing-membership/. Accessed 12 June 2015.

${ }^{51}$ Membership lists are available on each UK CCP's website, ibid, reviewed on 12 June 2015.

52 While the focus here is on UK CCPs, responses provided to the European Commission's ongoing EMIR review, discussed in note 119 below, suggest that there are similar dynamics in other Member States. For example, the responses from the Banque de France and the Ministère des Finances et des Comptes Publics raise concern about 'concentrating exposures towards a few clearing members which provide the access to central clearing' (in the answer to the consultation's question about client clearing relationships) while the Netherlands Authority for the Financial Markets states in its response that 'the limited access to CCPs through a small number of large clearing members therefore seems to create a significant operational, legal and economic burden for small financial and non-financial counterparties' (in its answer to the same question) and the Czech Banking Association describes in detail the costs of accessing clearing in its jurisdiction and the problems that some market participants have had finding a member to clear through. (Responses to the EMIR consultation questionnaires are available at http://ec. europa.eu/finance/consultations/2015/emir-revision/index_en.htm (last accessed 4 November 2015)). Overall, the ECB 'recommends that the question on the use of, or access to, OTC derivatives by NFCs be studied further, and mitigants identified if it were to be confirmed that the current overall framework (including banking regulation and market infrastructure regulation) causes specific undue restrictions for NFCs and their businesses', ECB (2015), at p. 7.
} 
with that CCP' 53 'Client clearing' therefore involves a client accessing clearing by contracting with an eligible member of a CCP.

In Europe, members of CCPs are either 'individual members', which may clear solely on their own behalf, or 'general clearing members', which may also clear for their clients. In the US, members are either clearing members, which may clear proprietary trades and trades on behalf of non-US domiciled clients, or futures commission merchants (FCMs). FCMs are required to be registered with the Commodity Futures Trade Commission and, in addition to the activities open to clearing members, they may also clear on behalf of US-domiciled clients. ${ }^{54}$ In this article, as the focus is on the EU clearing regime, the term 'members', unless otherwise defined, refers to general clearing members, and the term 'clients' refers to entities defined as such in EMIR.

EMIR provides that clearing members may only clear for clients if they have 'the necessary additional financial resources and operational capacity to perform this activity'. ${ }^{55}$ In practice, client clearing is often one of a bundle of services provided by a prime broker to its client, along with secured lending and custody arrangements. As regards clearing, the prime broker/clearing member may offer related services such as collateral transformation, whereby lower-quality assets are swapped at a discount or 'haircut' for higher-quality ones, which are accepted by a $\mathrm{CCP}$ as margin. In return for these services, the member will charge fees which may be calculated in a variety of ways, ${ }^{56}$ and may also benefit from a right of use over excess margin posted by the client but not due to the CCP, for instance, because of the effects of position netting.

In legal terms, there are two main ways that a client may structure relations with its clearing member. ${ }^{57}$ In Europe, the 'principal to principal' model is the norm. In this case, the client is principal in its dealings with the member and the member is principal in its dealings with the CCP. The client and CCP have no contractual relationship, and there are separate, bilateral contracts between the member and client, and the member and CCP. The principal-to-principal model is reflected, for example, in the CCP's fee arrangements. SwapClear's published information for members, for example, makes it clear that all fees for clearing services will be charged to members, not clients, and then it is up to members to make individual pricing arrangements with their clients. ${ }^{58}$

The drafting of the documentation between client and member will be complex. It must attempt to replicate the relevant membership obligations of the $\mathrm{CCP}$, and, in particular, provide for the provision of margin up this intermediated chain to the CCP. The clearing member will be concerned to match up their two sets of rights

\footnotetext{
53 Article 2(14) of EMIR.

54 SwapClear, Becoming a Member guide, available at http://www.swapclear.com/service/becoming-amember.html. Accessed 4 November 2015 .

55 Article 37(3) of EMIR.

56 Gregory (2014), at p. 213, explains that fees may be charged on a fixed fee and/or per transaction basis.

57 See diagrams in ibid, at pp. 208-9.

58 SwapClear, Client Clearing Fees, available at http://www.lchclearnet.com/asset-classes/otc-interestrate-derivatives/fees. Accessed 4 November 2015.
} 
and obligations, to ensure that the client is bound by the relevant membership rules of the CCP. Thus, the CCP's requirements for clearing will have an indirect effect on the client, despite the fact that there is no privity of contract between them. To the extent that any of these obligations are not successfully matched up, the member assumes 'asymmetry costs', 59 for example, if a CCP demands that the member posts margin more frequently than the client has to post it to the member.

The structure used for client clearing in the US is agency-based. This means that the member deals with the CCP as agent for the client, with the result that, unlike in Europe, the client and CCP have a contract with one another. The clients' obligations to the CCP are guaranteed by the clearing member. Given the focus on the EU, this article will proceed on the basis that the principal-to-principal model is in place.

\subsection{Indirect Clearing}

A third way of accessing clearing involves a market participant becoming an 'indirect client', defined in the EU rules as 'the client of a client of a clearing member'. ${ }^{60}$ Compared to client clearing, an indirect client is one step further removed from the CCP. It follows that the arguments developed about client clearing also apply to the longer contractual chain involved in indirect clearing, and many of the legal concerns will be the same in both contexts.

Indirect clearing is largely overlooked in EMIR itself, but, having been 'introduced [into ESMA's brief] at the last minute', ${ }^{61}$ it has since been addressed in Commission Delegated Legislation. ${ }^{62}$ The Consultation Paper circulated by ESMA prior to the publication of the Commission Delegated Regulation noted respondents' views that indirect clearing is 'a relatively new concept and that market practices continue to evolve'. ${ }^{63}$ This Commission Delegated Regulation, now in force, seeks to ensure that 'any type of indirect clearing arrangements comply with minimum conditions for ensuring their safety' 64 and that indirect clients have 'equivalent protection ... as granted to clients under Regulation (EU) No 648/2012,65 including 'in a default scenario'. 66 For example, the Delegated Regulation extends the protections afforded by EMIR to clients, such as porting, to indirect clients. ${ }^{67}$ It is also notable for setting out standards for each of the parties in the indirect clearing chain (apart from the end-user itself), being the CCP (Article 3), the clearing member (Article 4) and the clients (Article 5). As regards members, they are required to facilitate indirect clearing by their clients on 'reasonable commercial

\footnotetext{
59 Discussed at Gregory (2014), at p. 213.

60 Article 1(a), Commission Delegated Regulation (EU) No 149/2013.

61 ESMA (2012), para. 16, at p. 8.

62 Articles 1-5 inclusive, Commission Delegated Regulation (EU) No 149/2013.

63 ESMA (2012), para. 18.

64 Recital (4), Commission Delegated Regulation (EU) No 149/2013.

65 Recital (5), ibid.

66 Recital (6), ibid.

67 Article 4(4), ibid.
} 
terms' ${ }^{68}$ At the same time, the rules recognise the possibility of the membershiplike burdens being imposed by members in such circumstances. Thus, the Delegated Regulation provides that terms which members impose on any clients offering indirect clearing services 'may include minimum operational requirements' ${ }^{69}$

Finally, as Gregory explains, indirect clearing may also be necessary where a European bank has clients who wish to clear in the US. Under US rules, CCP members must be registered FCMs, so a European bank would have to become a client of an FCM for its own clients to access clearing. ${ }^{70}$

\subsection{Limitations of Access Arrangements}

Membership of CCPs clearing OTC derivatives therefore remains onerous, but there are other ways to gain access to clearing. Given the sweeping effects of the EMIR clearing obligation, these routes are of increasing importance. There remain, however, significant concerns about how these means of accessing clearing will work in practice.

First, client and indirect access arrangements exacerbate the type of market interconnectedness that regulators intended to reduce by introducing compulsory CCP clearing. As we have seen, client clearing and indirect clearing are both based upon networks of contracts which converge on a relatively small number of financial institutions in their capacity as CCP members.

The second drawback of client and indirect clearing arrangements is that they mitigate rather than solve the membership dilemma. In other words, it remains possible that a non-exempt market participant wishing to trade a product subject to the clearing obligation may not be able to secure access to a CCP. Even though EMIR acknowledges the importance of openness, CCPs (rightly) cannot be required to take an entity on as a member. ${ }^{71}$ Nor are members obliged to clear for any given client. Indeed, there may be good reason to refuse to clear for a particular entity. Thus, de facto exclusion from clearing is possible, though the EU regime is silent on this scenario.

The final drawback of client clearing, and the issue that is examined in detail for the remainder of this article, arises from its impact on the 'asset-backing' of cleared contracts. Client clearing requires assets such a securities and cash to move up and down a contractual chain, along which the assets comingle, pass through different accounts, and are likely to be rehypothecated (or lent out again) to third parties. Each step potentially creates risk for the client. This particular type of risk should be of acute concern for clients given, first, that many clients will be non-dealers new to clearing, with conservative risk profiles, and secondly, because recent events in the financial markets have demonstrated how even carefully segregated client assets may be vulnerable in times of market stress.

\footnotetext{
68 Article 4(1), ibid.

69 Article 4(1), ibid.

70 Gregory (2014), at p. 128.

71 EMIR preserves a CCP's right to refuse membership to entities meeting its membership criteria, so long as this refusal is based on a 'comprehensive risk analysis', Article 37(5), EMIR.
} 
Client assets did not have a good crisis. Client asset rules and market-standard contracts were both found to be wanting in the case of brokers' insolvencies, so that client assets were not returned promptly, or even subjected to an unexpected shortfall. The collapse of Lehman Brothers International (Europe) Ltd (LBIE), the London-based broker and derivatives dealer, triggered long-running and controversial litigation about paying out client money, including that which was meant to be held on a statutory trust. This culminated with the Supreme Court's controversial decision interpreting the Financial Services Authority's (FSA) client money rules (found in the Client Assets Sourcebook, or CASS). ${ }^{72}$ In brief, the court held that the pool of segregated client money was to be shared even by clients whose assets had not been segregated by LBIE. Understandably, this outcome was met with great concern by the markets.

The collapse of LBIE also demonstrated the shortcomings of private arrangements for holding client assets. In an LBIE case considering a standard-form prime brokerage agreement, Briggs $\mathbf{J}$ (as he then was) considered the parties' terms in detail, finding them silent on the matters in hand. After considering various possibilities in law and equity, this decision rescued the clients' proprietary rights over cash generated from their securities by taking the unusual step of implying a contractual term in the relevant agreement. ${ }^{73}$ The October 2011 collapse of the broker-dealer MF Global UK Ltd triggered further litigation about client assets, which once again demonstrated the uncertainties of the UK legal regime. ${ }^{74}$ For regulators, these events helped to spark a wholesale review of CASS, which started with a consultation paper in September 2012. For market participants, this spike of litigation continues to serve as a stark warning about the potential vulnerability of client assets.

In conclusion, this part of the article has shown how the clearing obligation in EMIR (along with similar rules in other jurisdictions) creates tension between CCP autonomy and inclusiveness. A CCP's autonomy to choose its members remains central to its risk management, while, at the same time, inclusiveness is assumed by regulatory reforms. This is one of the implications of embedding privately owned entities into mandatory public sector reforms. There are, of course, links here with debates about fair access to other financial market infrastructures, such as payment and securities settlement systems, but what this part of the article has shown is that the case of CCPs is uniquely pressing, because regulators have chosen to make clearing compulsory and because CCPs mutualise losses between their members. In this sense, the response to one lesson of the crisis (namely, the risks associated with OTC derivatives) may well be underestimating another (the risks associated with client assets). The problems which may result are considered in the final Section of the article, which examines in detail the interaction between client clearing and the posting of margin to CCPs.

\footnotetext{
72 Re Lehman Brothers International (Europe) [2012] UKSC 6, on appeal from [2010] EWCA Civ 917 and [2009] EWHC 3228 (Ch).

73 Re Lehman Brothers International (Europe) [2009] EWHC 2545 (Ch).

74 See Re MF Global UK Ltd (in special administration) (No 2) [2013] EWHC 92 (Ch), [59]-[68].
} 


\section{Client Clearing and CCP Margin Arrangements}

Margin is fundamental to clearing, as is reflected in EMIR's definition of clearing as

'... the process of establishing positions, including the calculation of net obligations, and ensuring that financial instruments, cash or both, are available to secure the exposures arising from those positions. ${ }^{75}$ [this author's emphasis]

Margin provides the means by which a $\mathrm{CCP}$ is able to assume the risk of standing in the middle of each trade that it clears, acting as a 'shock absorber' for the market should a participant fail. A clearing member is required to post two types of margin to the CCP: initial margin (IM) and variation margin (VM). VM is margin collected or paid out as determined by changes to the mark-to-market value of a contract. ${ }^{76}$ It is calculated by the CCP on a regular basis which, in the case of OTC derivatives, might be daily or even intra-day. IM is collected on the basis of a CCP's estimation of the losses it might face due to the event of a default of a member, during the period from when the last VM has been received and the time when the contract can be liquidated. ${ }^{77} \mathrm{~A}$ member must also contribute to the CCP's default or 'guaranty' fund. The role of this fund is to mutualise losses not covered by a defaulting member's margin. EMIR requires a default fund to be able to withstand scenarios based on 'extreme but plausible market conditions'. ${ }^{78}$

In the case of a default, a member's VM and IM provide the first two lines of defence which a CCP will use to cover any losses. It is noteworthy that this has been sufficient of a buffer in many defaults in the past: Gregory reports that in the seven defaults experienced by LCH. Clearnet to date, all losses have been managed with recourse to the defaulter's margin alone. ${ }^{79}$ However, should further assets be needed, a CCP will work through what is referred to as the 'default waterfall' of resources. This is partly prescribed by Article 45 of EMIR. ${ }^{80}$

\footnotetext{
75 Article 2(3) of EMIR.

76 See definition at Article 1(6), Commission Delegated Regulation (EU) No 153/2013.

77 See definition at Article 1(5), ibid, and Murphy (2013), at p. 148.

78 Article 42(3) of EMIR. How a CCP is to identify and review its definition of 'extreme but plausible market conditions' is further prescribed by Articles 30 and 31, Commission Delegated Regulation (EU) No 153/2013. A CCP has to take into account 'at least' historical data, including periods of extreme market movements, from the last 30 years 'or as long as reliable data have been available' and 'potential future scenarios'.

79 Gregory (2014), at p. 177.

80 The default waterfall is presented in list form at Murphy (2013), at p. 149. Note that Article 45(4) of EMIR states that a CCP may not use margins posted by non-defaulting members to cover the losses from a defaulting member. The layer of the default waterfall made up by the CCP's own resources is further dealt with by Articles 35 and 36, Commission Delegated Regulation (EU) No 153/2013. See CME Group's version of the waterfall at CME Group, Financial safeguards: protecting customers against default, at http://www.cmegroup.com/europe/clearing-europe/risk-management/financial-safeguards. html. Accessed 4 November 2015. For the ongoing debate about what should happen if losses prove greater than assets available in the conventional default waterfall, and if questions of resolution arise, see Bailey (2014).
} 
The subject of this Section is how the collection and use of margin works in the context of client clearing. When client clearing takes place, the basic principle of a party having to back up its cleared positions with assets remains the same as described above. Accordingly, under the principal-to-principal model, the objective is that margin should be posted by the client to the member, and then by the member on to the CCP. If the client defaults, its margin should be available for the CCP to use to cover losses from positions cleared on its behalf by the member. If the member defaults, the aim under EMIR is that the client's positions and assets should be 'ported', or transferred, to a new, solvent member to allow continuity for the client.

In practice, however, matters are complicated by adding the 'client-member' tier (and a further 'indirect client-client' tier, if applicable) because these arrangements raise a large number of technical legal issues. This article does not attempt to work through all of these technical legal issues, but by way of example of the complexities which may be caused by overlapping legal rules in this sector, it considers the interaction of the EMIR regime and UK national rules on client assets. $^{81}$

\subsection{The Legal Regime for Client Clearing: EMIR}

Given the complexity of the issues presented by client clearing, there are surprisingly few details about it in EMIR, and there is no directly related Commission delegated regulation. ${ }^{82}$ Articles 39 (Segregation and portability) and 48 (Default procedures) are the main source of relevant rules in EMIR, ${ }^{83}$ and, perhaps unsurprisingly given the preceding discussion, they are almost exclusively concerned with margin and the arrangements for holding it.

The central requirement of Article 39 is that CCPs make two types of accounts available to members clearing for clients, as a minimum. Under Article 39(5), a clearing member has to pass on the same choice to its clients. The first type of arrangement that CCPs are required to offer is described as 'omnibus client segregation' (Article 39(2)), and the second is 'individual client segregation'

\footnotetext{
81 On the basis of responses to the ongoing EMIR review, discussed further infra n. 119, the complexities and costs of client clearing are a cause for concern in other Member States apart from the UK. As already noted, the ECB's response to the consultation calls for further analysis of the impact of EMIR on NFCs generally (ECB 2015, at p. 6). This response also suggests implementing more 'granular' EU rules on client clearing, segregation and portability (ECB 2015, at pp. 21-22). Other returns to the EMIR review express concern about the burdens and risks of client clearing (see supra n. 52). Amongst responses calling for further analysis of overlapping rules in this context, the joint response from Banca d'Italia and CONSOB explains in detail why there should be a review of how EMIR and the Settlement Finality Directive interact in the case of individual client segregation, and also states that 'a specific in-depth analysis should be envisaged in the case of indirect clearing' (Banca d'Italia and CONSOB (2015), at p. 12).

82 The Financial Markets Law Committee (FMLC) has criticised the 'absence of any power for the Commission and ESMA to develop Level 2 regulatory technical standards on the operation of either Article 39 or Article 48 of EMIR'. It has suggested that the FCA seek to address this issue at EU level, FMLC (2014), at p. 17.

83 Articles 2-5 inclusive, Commission Delegated Regulation (EU) No 149/2013 cover indirect clearing, including replicating the effects of Articles 39 and 48 of EMIR (for client clearing) in this context.
} 
(Article 39(3)). EMIR prescribes the basic features of these accounts but gives little detail: for example, it does not specify whether the positions of clients participating in an omnibus client account should be margined on a net or gross basis. ${ }^{84}$

In the 'omnibus client segregation' arrangement, EMIR requires CCPs to keep separate records and accounts to enable each clearing member to 'distinguish in accounts with the CCP the assets and positions of that clearing member from those held for the account of its clients'. In other words, the member's house account will be kept separate to its single, 'omnibus' client account. Article 39(9) goes on to explain that to 'distinguish in accounts' means that assets and positions are recorded in separate accounts (i.e., here a member will have a house account and a client account); that netting between different accounts is prevented; and that assets in one account may not be used to cover losses relating to positions recorded in another account.

This omnibus model has several advantages. First, the member may post net VM and IM on its net client portfolio (though, as noted above, EMIR is silent on exactly how to work this out). Because some clients' positions are likely to cancel each other out, the member is therefore likely to hold more client margin than it is required to post to the $\mathrm{CCP}$. This is an advantageous arrangement for the member, which will be able to keep this excess margin, and, if applicable, exercise its right of use powers (i.e., it may use the excess margin as collateral for its own activities). On the other hand, it is potentially problematic for clients, who may have an exposure to the clearing member for part of its margin in the event of its default.

A further disadvantage of this omnibus arrangement for clients is that there are no assets at the clearing house level which are identifiable as the individual client's own. This means that the omnibus model represents the weaker position for the client in terms of, first, portability and, second, vulnerability to the default of other parties.

Portability refers to the option of a client moving its portfolio from one member to another member, typically in the event of a default by the original member. ${ }^{85}$ Article 48(5) of EMIR deals with porting under the omnibus segregation model. It provides that the CCP shall

'at least, contractually commit itself to trigger the procedures for the transfer of the assets and positions held by the defaulting clearing member for the account of its clients to another clearing member designated by all of those clients, on their request and without the consent of the defaulting clearing member.'

It is notable that under the omnibus model, all clients' assets and positions have to move as one to a new member. Moreover, as this Article is silent on the decision-

\footnotetext{
${ }^{84}$ Discussed in FSA (2012), at p. 10. The difference is explained by the FSA as between netting all clients' positions and providing margin on that basis, or netting each client's positions and providing margin on 'gross per client'.

85 However, as Murphy (2013), at pp. 159-160, has noted, porting requires a client's margin to be able to move with its contracts and in practice, this would be difficult to arrange in a crisis without having a preexisting relationship with the "backup" clearing member'. He suggests that porting would in fact require a client to have arrangements with two members to begin with.
} 
making practicalities involved in 'all ... clients' designating a new member, or making a 'request' to port, this detail will be something for clients to check carefully for themselves. The second part of Article 48(5) includes the important qualification that the new member is only obliged to accept these porting clients where it has previously made a contractual commitment to do so. This is unsurprising, as it would not want to accept this burden in the heat of the moment without proper due diligence. ${ }^{86}$ In practice, porting may be impossible anyway if the unsegregated margin has been used up because of the mutualisation of the losses of other defaulting parties. This may be the case, as Murphy shows, if the CCP closes out against the whole client portfolio, when it will have available the comingled client margin as a whole. In these circumstances, a non-defaulting client has a 'fellow client risk'. ${ }^{87}$

The alternative model set out in Article 39(3) of EMIR is the individual client segregation model. In this case, CCPs must offer arrangements so that members can 'distinguish in accounts' each client's assets and positions from those of other clients. In practice, under this model, each client's margin will be kept in a separate account by the CCP. This is the preferred EMIR model in terms of portability and client protection. Article 48(6) reflects this, stating that the client may, on its own, request porting, designate a new member and have its assets and positions moved. In the ordinary course of events, however, individual client segregation is less operationally convenient for the member, not least because it requires the member to post all of the margin it receives from the client. For these reasons, it will be more costly for the client.

Finally, it should be remembered that the EMIR framework sets out the minimum choice that a CCP has to offer. In practice, CCPs are marketing an array of offerings above and beyond this minimum. For example, CME Clearing Europe offers what it describes as a 'fully segregated Client account' ${ }^{88}$ The clearing house states that this 'unique form of Client account offers more collateral protection than any other account available'. The central aim behind this option seems to be that the entity posting securities as initial margin may do so while keeping them at an account with a custodian in the clearing house's name, in other words, it avoids having to move them through a clearing member. ${ }^{89}$ Rather than a binary choice with stark trade-offs between price and protection, therefore, CCPs' offerings go beyond the minimum in EMIR and allow parties a choice to suit their budget and appetite for risk. ${ }^{90}$

\footnotetext{
86 The backstop position is set out at the end of A48(5): if porting is not possible, the CCP 'may take all steps permitted by its rules' to manage the positions held by members for clients.

87 See Murphy (2013), at p. 170 as well as the diagrams on pp. 169-172 detailing losses in a range of default scenarios.

88 CME Group, Enhanced Client Protections, http://www.cmegroup.com/europe/clearing-europe/riskmanagement/customer-protection-and-segregation.html. Accessed 4 November 2015.

89 Ibid.

90 Legally separated, but operationally comingled (LSOC) is another sort of interim position between full segregation and the omnibus model. In the LSOC model, margin with respect to clients' positions is held in a single account, but unlike the omnibus model, the CCP's records reflect the value of margin of each client $\mathrm{X}$ and $\mathrm{Y}$. If X defaults, only X's margin can be used to cover its losses, and therefore Y's margin is more secure than it would be under the omnibus model. In the US, regulators require CCPs to use this LSOC compromise. See SwapClear, Customer Protection Dodd-Frank, available at http://www. swapclear.com/service/customer_protection_dodd_frank.html. Accessed 4 November 2015.
} 


\subsection{UK Rules: CASS}

In the UK, perhaps the most significant regulatory implication of client (and indirect) clearing is that it imports a further set of legal rules into the clearing process. These are the recently reformed ${ }^{91}$ CASS rules in the FCA's Handbook, ${ }^{92}$ and the interaction with EMIR is far from straightforward.

As at 2013, the FCA's client assets regime covered 1500 firms, $£ 10$ trillion of custody assets, and $£ 100$ billion of client money. ${ }^{93}$ It is important to note at the outset that the FCA's CASS rules do not apply to CCPs, ${ }^{94}$ but as the FSA explains in a December 2012 Policy Statement, they become relevant when client clearing is used because

"[c]learing members of CCPs will often be "firms" as defined in the FSA Handbook, who hold client money for the purposes of the CASS rules. Margin transferred by a firm to a client account at a CCP may be client money from the perspective of the clearing member. ${ }^{95}$

These rules are designed to regulate a huge range of business activities ${ }^{96}$ and they do not always sit easily with the technical and CCP-tailored EMIR regime. The fragmentary application of these rules in the clearing context is exacerbated by two further factors.

First, CASS is 'broadly speaking, only applicable to UK firms and their EEA branches'. ${ }^{97}$ This means that some clearing members of a UK CCP will not be subject to CASS. For instance, as the FMLC observes in its recent report, CASS will not apply 'where a clearing member is an incoming EEA firm subject to Home State regulation of its operational arrangements under client money' ${ }^{98}$ Nor will CASS apply to protect UK clients using members based outside the EU, e.g., to provide UK clients with access to a third-country CCP. ${ }^{99}$

Secondly, even if all members of a CCP were UK firms, CASS would still not apply to all of their transactions. This is because CASS only applies to transactions involving 'client money'. So, for example, the FMLC points out that CASS does not

\footnotetext{
91 Changes have been phased in, with the latest reforms taking effect on 1 June 2015.

92 The CASS rules may be found in the FCA Handbook, at https://www.handbook.fca.org.uk/handbook/ CASS/.

93 FCA (2013), para 1.8.

94 FSA (2012), at p. 20.

95 Ibid, para. 1.8 .

96 CASS covers authorised persons undertaking all regulated activities (CASS 1.2), for example, occupational pension schemes, stock lending and prime brokerage (CASS 1.4).

97 FSA (2012), at p. 9.

98 FMLC (2014), at p. 14.

99 FSA (2012), at p. 9.
} 
apply to those members accepting deposits as a bank. ${ }^{100}$ Furthermore, it does not apply to any margin provided by clients to members by way of a title transfer collateral arrangement (TTCA).

A TTCA is a popular type of financial collateral arrangement ${ }^{101}$ which a provider of collateral may choose to use as an alternative to a security financial collateral arrangement. ${ }^{102}$ There are important legal differences between these two types of arrangements. When providing security, the client retains a property interest in the assets, though the member will usually enjoy a contractual 'right of use' over the assets. ${ }^{103}$ By contrast, under a TTCA, the client retains no property rights in the assets and only has a contractual right to the return of equivalent assets. This means that whenever a TTCA is used, 'money cannot be said to be held on behalf of that client'. ${ }^{104}$ Therefore the protections afforded to client money and client assets in CASS will not apply if a TTCA is used. ${ }^{105}$ This is reflected in the fact that the amended CASS rules require TTCAs to be evidenced in writing. ${ }^{106}$

Notwithstanding this only partial overlap, EMIR significantly complicated the reform of CASS, as the latter rules had to be specially adapted to accommodate the particular legal arrangements used in client clearing. In some cases, special rules had to be written, so that CASS now includes CCP-specific provisions. The most prominent example was added to allow for clearing practices that would otherwise clash with the overarching principle in CASS 7 and 7A, namely that upon the failure of a firm, client assets should form a 'single notional pool of client money for the beneficiaries of the general pool'. ${ }^{107}$ Instead, clearing members are specially permitted to create separate sub-pools of client money for clients clearing through a net margined omnibus client account. The use of a sub-pool means that assets belonging to defined beneficiaries will not form part of a general pool of client assets on the insolvency of the clearing members, and that any shortfall should be confined to a particular pool and not borne by all clients. ${ }^{108}$ Most importantly, a subpool should facilitate porting ${ }^{109}$ in the event of the failure of the clearing member,

\footnotetext{
100 Ibid, at p. 14.

101 Ibid, at p. 11, noting that 'a few respondents' to the FSA's September 2012 consultation felt that TTCAs were 'prevalent' in this context. The FSA seems to query this, but concedes 'so many people asked us about this' it was necessary to deal with the topic at some length in the policy statement.

102 Both are defined in Article 2 of Financial Collateral Arrangements Directive 2002/47/EC.

103 This right of use is protected by Financial Collateral Arrangements Directive 2002/47/EC and, in the context of the CCP's holding of the margin and assets in the default fund, the right of use is re-confirmed by Article 39(8) of EMIR.

104 FSA (2012), at p. 11.

${ }^{105}$ CASS 6.1.7G and CASS 7.11.1R(1) respectively. See also CASS 7.11.5(G): 'A title transfer financial collateral arrangement under the Financial Collateral Directive is an example of a type of transfer of money to cover obligations where that money will not be regarded as client money.'

106 See the new CASS rules about how firms document their TTCAs (affecting new and current TTCAs) and clarifying the procedure for clients wishing to swap out of TTCAs and hold assets as 'client money' instead, as discussed in FCA (2014), at pp. 52-54.

107 CASS 7A 2.4R(1)(b).

108 FCA (2014), at pp. 25-30.

109 Porting is expressly recognised in CASS 7A.2.4AG(1).
} 
by making sure enough margin is available on a client-by-client basis. ${ }^{110}$ Indeed, the FCA states that this was the underlying objective of this change to the rules. ${ }^{11}$ The use of sub-pools may be reassuring for clients, but, as the FCA concedes, it involves 'operational complexities ${ }^{112}$ and may open the member up to litigation from clients attempting to share in sub-pools in a default. ${ }^{113}$

In addition to these clearing-specific rules, other parts of CASS have been waived solely for clearing members. For example, there is an exemption provided for CCP members from the new rule about the 'immediate segregation' of client and house money. Ordinarily, the 'immediate segregation' rule requires firms to receive client money directly into the client bank account, rather than through the firm's own account. This requirement would, however, be a problem for CCP members involved in client clearing, because of the interaction of EMIR with this rule. Specifically,

'clearing members are likely to be required by CCPs to make and receive single payments that relate to both proprietary accounts and client segregated accounts at the CCP from/into a single bank account.' ${ }^{114}$

The requirement to segregate client money immediately would therefore not work in this context. The conclusion reached by the FCA was that the final rules had to 'make specific allowance for this scenario'. ${ }^{115}$ As at 1 June 2015, therefore, CASS provides that firms clearing for clients will not be subject to the 'immediate segregation' rule if they have used 'reasonable endeavours' 116 to arrange for the CCP to pay client and house margin separately and this is still not available. Instead, they have to meet a set of conditions, including using a house account for mixed payments, segregating client assets promptly, and maintaining in the client accounts a 'prudent' sum of money which will act as a buffer if something goes wrong with this substitute process and there is a shortfall. ${ }^{117}$ Thus, EMIR has resulted in special accommodation in CASS for firms, and a lot of discretion being left to the CCP in this context. Seen alongside the other carve-outs made for CCPs and clearing members, ${ }^{118}$ a pattern emerges which suggests that CASS not only applies in a piecemeal way, but that it is an awkward fit when it does so.

\footnotetext{
110 As discussed in one law firm's response to the September 2012 consultation paper: Freshfields Bruckhaus Deringer (2012), at p. 5.

111 FCA (2014), para. 4.12.

112 Ibid, para. 4.7. This may also be traced through from the original proposal for sub-pools to be more broadly available.

113 Ibid, para. 4.6.

114 Ibid, para. 7.117.

115 Ibid, para. 7.121.

116 CASS 7.13.72R.

117 CASS 7.13.71R-7.13.79G inclusive. This buffer is called the 'clearing arrangement mandatory prudent segregation amount' or 'CAMPSA', as discussed in FCA (2014), para. 7.121.

118 For example, carve-outs have been made to the requirements for certain letters to be written to thirdparty holders of client money. FCA (2014), para 7.327.
} 


\subsection{Implications}

It was only to be expected that UK regime for client assets would be thoroughly overhauled after the stark problems revealed during times of market stress, including those problems which came to light in the LBIE and MF Global litigation. However, this process has been complicated by the fact that, because of client clearing, these rules apply in the CCP context, which was, simultaneously, being reformed in radical ways. The interaction between client asset rules and EMIR has impacted upon the FCA's reforms, and resulted in multiple carve-outs and special rules solely for clearing, though significant practical and conceptual difficulties still remain. As a result, the UK client asset regime has become more fragmented and more sector-specific, for example, as regards the rules about 'sub-pools'. In turn, carve-outs and special rules serve to exacerbate the piecemeal regime governing assets deployed for client clearing. They increase the complexity for firms required to comply with CASS, for clients and for CCPs, and, as regulators have speculated, they may intensify legal risk in the clearing sector.

How might this complexity be addressed? The particular clashes and complexities described above would, of course, be immediately addressed if firms that are clearing members of CCPs were exempted from the CASS regime for their client clearing activities. This would drastically simplify the current piecemeal rules affecting margin in the CCP context. This move would, however, remove a swathe of protections for certain clients using this UK financial market infrastructure. Given recent high-profile client asset failures, and the very recent reforms to CASS which made bespoke arrangements for firms involved in clearing, a wholesale carve-out seems very unlikely to happen in practice.

Accordingly, the best option is to look to the EU. As part of the ongoing EMIR review ${ }^{119}$ regulators should seek to improve the legal regime governing clearing, including by addressing the inconsistent application of, and interaction with, client asset rules. Given the heightened significance of client clearing under a mandatory clearing regime, as outlined above, this would be a highly appropriate use of the review process outlined in Article 85 of EMIR. ${ }^{120}$ One possibility is to consider requiring CCPs to use their membership agreements to apply those client asset rules specially designed for clearing members (e.g., CASS 7.19 on clearing member client sub-pools) to all members clearing for clients, regardless of whether they are authorised firms. In this way, CCPs would be using contracts to replicate protections which are currently imposed by public sector regulation on only a portion of

\footnotetext{
119 Article 85 of EMIR requires that the Commission shall review and prepare a general report on EMIR by 17 August 2015. However, the process is running late. The public consultation document called for responses by 13 August 2015 (European Commission 2015, at p. 3) and, as at November 2015, the European Commission's Consultation webpage reports that there have been 185 responses, and that a 'summary of responses will be published ... at a later stage' (http://ec.europa.eu/finance/consultations/ 2015/emir-revision/index_en.htm). This article was submitted for publication before these responses were published online, though it was possible to review the responses while finalising the article. See supra nn. 52 and 81.

${ }^{120}$ The FMLC suggested that a Delegated Regulation should set out technical standards with respect to Articles 39 and 48 of EMIR in the context of conflicting claims over excess margin held by the CCP member, FMLC (2014), at p. 17.
} 
members and transactions. This article has identified several other issues which could usefully be addressed in the course of this review. First would be to rectify the unjustified separate treatment of client clearing (dealt with in EMIR) and indirect clearing (dealt with in Commission Delegated Legislation). Given the fundamental legal structures shared by these two types of access arrangement, they should be addressed together in the same, more comprehensive, set of rules. In any event, the EMIR review should also seek to resolve other, basic uncertainties around access to client clearing, including the uncertainties around de facto exclusion from membership and around the transparency of client and indirect clearing arrangements. But this article has argued that the overriding objective of any review of client clearing under EMIR should be to protect clients' assets or margin in a consistent and legally certain way. This is just as important a lesson of the recent financial crisis as the risks of the OTC derivatives markets. These issues are legally complex, but now framework legislation for regulatory reform is in place in major jurisdictions, the aim should be to tackle those important questions of law which are currently unresolved or governed by piecemeal rules, while leveraging, rather than reducing, CCPs' autonomy to govern their members and ensure safe and robust clearing services.

\section{Conclusion}

While the new regulatory regime for OTC derivatives depends on safely functioning CCPs, CCPs depend on selecting their own members and requiring them to post margin. As CCPs start to assume their greatly enhanced role in the OTC derivatives markets, there are many implications for lawyers to consider. This article has focused on some of them, by exploring the dilemma between CCP inclusivity and autonomy, and considering how the partial solution of client clearing generates various legal risks. It has focused on explaining certain of those risks in detail. In particular, it has analysed how the vitally important process of posting of assets for clearing purposes is complicated by arrangements allowing access in the first place.

Ultimately, the importance of the specific legal issues highlighted in this article is inversely proportionate to how inclusive CCPs are towards new members. If CCPs were to drastically lower entry and monitoring criteria, if membership became cheaper and less onerous, and if more parties were willing and able to sign up, client clearing would become less important an aspect of the clearing regime. However, such changes would be nothing short of a revolution for the CCP industry, and there are, as yet, no signs that this will happen on a significant scale. The PFMI and EMIR fall far short of calling for such changes, ultimately upholding the principle of CCP autonomy in their respective provisions about membership criteria. Assuming, therefore, that client clearing is here to stay, lawyers must do more to join economists and bankers in debating its impact and effects. Client clearing is rich in legal issues. It involves assets moving around networks of contracts between clients, indirect clients, CCPs and a small number of members. For this reason, it disrupts the neat 'hub and spoke' picture of CCPs preferred by many commentators, but recognising this more legally complex reality is a necessary part of implementing 
the G20's objectives, and it is essential if CCPs are to safely fulfil the systemically important role which regulators have chosen to assign to them.

Open Access This article is distributed under the terms of the Creative Commons Attribution 4.0 International License (http://creativecommons.org/licenses/by/4.0/), which permits unrestricted use, distribution, and reproduction in any medium, provided you give appropriate credit to the original author(s) and the source, provide a link to the Creative Commons license, and indicate if changes were made.

\section{References}

Bailey D (2014) The Bank of England's perspective on CCP risk management, recovery and resolution arrangements. http://www.bankofengland.co.uk/publications/Pages/speeches/default.aspx. Accessed 4 Nov 2015

Banca d'Italia and CONSOB (2015) Responses to the public consultation on Regulation 648/2012 on OTC derivatives, central counterparties and trade repositories. https://ec.europa.eu/eusurvey/ publication/emir-revision-2015?language=en. Accessed 4 Nov 2015

Bank of England (2015) The Bank of England's supervision of financial market infrastructures-Annual Report

Basel Committee on Banking Supervision (BCBS) (2014) Capital requirements for bank exposures to central counterparties. http://www.bis.org/publ/bcbs282.htm. Accessed 4 Nov 2015

Benjamin J (2007) Financial law. OUP, Oxford

Braithwaite J (2011) The inherent limits of 'legal devices': lessons for the public sector's central counterparty prescription for the OTC derivatives markets. Eur Bus Organ Law Rev 12:87

Braithwaite J (2012) Standard form contracts as transnational law. Modern Law Rev 75:779

Committee on Payment and Settlement Systems and International Organization of Securities Commissions (2012) Principles for financial market infrastructures

European Commission (2015) Public consultation on Regulation (EU) 648/2012 on OTC derivatives, central counterparties and trade repositories. http://ec.europa.eu/finance/consultations/2015/emirrevision/index_en.htm. Accessed 4 Nov 2015

European Securities and Markets Authority (ESMA) (2012) Consultation paper: draft regulatory technical standards for the Regulation on OTC derivatives. ESMA/2012/379

European Central Bank (ECB) (2015) European Central Bank response to the European Commission's consultation on the review of the European Market Infrastructure Regulation (EMIR)

Ferrarini G, Saguato P (2015) Regulating financial market infrastructures. In: Moloney N, Ferran E, Payne J (eds) The Oxford handbook of financial regulation. OUP, Oxford

Financial Conduct Authority (FCA) (2013) Review of the client assets regime for investment business. CP $13 / 5$

Financial Conduct Authority (FCA) (2014) Review of the client assets regime for investment business. PS14/9

Financial Markets Law Committee (FMLC) (2014) Issue 147: Client monies. Response to the consultation of the Financial Conduct Authority entitled 'Review of the client assets regime for investment business'

Financial Services Authority (FSA) (2012) Client assets regime: changes following EMIR. PS12/23

Financial Stability Board (2014) OTC derivatives markets reform: eighth progress report on implementation

Freshfields Bruckhaus Deringer (2012) Proposed changes to the client assets regime. Briefing

G20 Leaders' Statement (2009) The Pittsburgh Summit, 25-29 September 2009. http://ec.europa.eu/ archives/commission_2010-2014/president/pdf/statement_20090826_en_2.pdf. Accessed 4 Nov 2015

Gregory J (2014) Central counterparties: mandatory clearing and bilateral margin requirements for OTC derivatives. Wiley, Chichester

ISDA (2014) Dispelling myths: end-user activity in OTC derivatives. ISDA Research Study. http:// www2.isda.org/functional-areas/research/studies/. Accessed 4 November 2015

Lane T, Dion J, Slive J (2013) Access to central counterparties: why it matters and how it is changing. Financ Stab Rev (Banque de France) 17:169 
Moloney N (2014) EU securities and financial markets regulation, 3rd edn. OUP, Oxford

Morgan G (2012) Reforming OTC markets: the politics and economics of technical fixes. Eur Bus Organ Law Rev 13:391

Murphy D (2013) OTC derivatives: bilateral trading and central clearing. Palgrave, Basingstoke

National Commission on the Causes of the Financial and Economic Crisis in the United States (2011) The financial crisis inquiry report. Public Affairs, New York

Norman P (2011) The risk controllers. Wiley, Chichester

PWC (2013) The bottom line: enter EMIR, you're going to need a bigger boat. Financial Services Regulatory Brief. http://www.pwc.com/us/en/financial-services/regulatory-services/publications/ dodd-frank-emir-requirements.html. Accessed 4 Nov 2015

Persaud A (2015) The unintended consequences and possible mitigation of the clearing mandate for OTC derivatives. http://ssrn.com/abstract=2643501. Accessed 4 Nov 2015

Rennison J (2015) 'US “superior” to Europe on futures margin', Financial Times, 14 May 2015 